\title{
Diving and night-time behavior of long-finned pilot whales in the Ligurian Sea
}

\author{
Robin W. Baird ${ }^{1, *}$, J. Fabrizio Borsani ${ }^{2}$, M. Bradley Hanson ${ }^{3}$, Peter L. Tyack ${ }^{4}$ \\ ${ }^{1}$ Biology Department, Dalhousie University, Halifax, Nova Scotia B3H 4J1, Canada \\ ${ }^{2}$ Istituto Centrale per la Ricerca Applicata al Mare, via di Casalotti 300, 00166 Roma, Italy \\ ${ }^{3}$ National Marine Mammal Laboratory, 7600 Sand Point Way NE, Seattle, Washington 98250, USA \\ ${ }^{4}$ Biology Department, Woods Hole Oceanographic Institution, Woods Hole, Massachusetts 02543, USA
}

\begin{abstract}
Pilot whales Globicephala spp. have long been thought to be deep divers, yet little information is available on dive depths. During August 1999 we obtained detailed dive data from suction-cup-attached time-depth recorder/VHF radio tags deployed on 5 long-finned pilot whales G. melas. Pilot whales were tagged for short periods (average $5 \mathrm{~h} \mathrm{ind.}^{-1}$ ) in deep (>2000 m) waters of the Ligurian Sea, off the NW coast of Italy. During the day all 5 whales spent their time in the top $16 \mathrm{~m}$ of the water column, and visible surface activities consisted primarily of rest and social behaviors. Tags remained attached after dark on 2 whales and shortly after sunset both whales made several deep dives (max. 360 and $648 \mathrm{~m}$ ). Velocity on these deep dives was greater than during shallow dives either during the day or at night, suggesting that these deep dives function primarily for foraging. Our results confirm the supposition that long-finned pilot whales can dive deep, particularly within $2 \mathrm{~h}$ after sunset, which is the time that vertically migrating prey become more readily available as they move closer to the surface.
\end{abstract}

KEY WORDS: Diving · Foraging $\cdot$ Globicephala $\cdot$ Pilot whale · Diel behavior

Resale or republication not permitted without written consent of the publisher

Pilot whales Globicephala spp. have long been thought to be deep divers. One trained short-finned pilot whale G. macrorhynchus was documented diving to $504 \mathrm{~m}$ and possibly made a voluntary dive to $609 \mathrm{~m}$ (Bowers \& Henderson 1972). Based on the species of prey taken, Gannon (1995) suggested that long-finned pilot whales G. melas off the east coast of the US foraged at 70 to $165 \mathrm{~m}$ in depth, while Desportes \&

${ }^{*}$ Present address: NOAA, NMFS, 101 Pivers Island Road, Beaufort, North Carolina 28516, USA.

E-mail: rwbaird@is.dal.ca
Mouritsen (1993) suggested that around the Faroe Islands this species fed at depths between 100 and $500 \mathrm{~m}$. Like many cetaceans, however, dive depths of wild long-finned pilot whales have not previously been reported (Hooker \& Baird 2001). Here, we present the first dive data of long-finned pilot whales, obtained using suction-cup-attached time-depth recorders deployed on whales in the Ligurian Sea (approximate location $43^{\circ} 17^{\prime} \mathrm{N}, 7^{\circ} 30^{\prime} \mathrm{E}$ ), off the coast of northwest Italy.

Materials and methods. Field work was undertaken from a $15.5 \mathrm{~m}$ motor sailer and a $4.2 \mathrm{~m}$ inflatable. The tags used were the same as those used to study the diving behavior of several other species of cetaceans (Baird 1998a, Hooker \& Baird 1999, Baird et al. 2000, 2001). Each tag weighed about $400 \mathrm{~g}$ and contained a VHF radio transmitter (Telonics) with a $30 \mathrm{~cm}$ semirigid wire antenna, and a time-depth recorder (TDRMk6, Wildlife Computers), which was set to sample depth and velocity once per s, and water temperature once per $5 \mathrm{~s}$. One TDR recorded depth at $2 \mathrm{~m}$ increments (accuracy: $\pm 2 \mathrm{~m}$ ), while the others recorded depth at $8 \mathrm{~m}$ increments (accuracy: $\pm 8 \mathrm{~m}$ ), and the maximum depth range of the instruments was 500 or $2000 \mathrm{~m}$, respectively. Velocity was measured by rotation of a paddlewheel; these readings are presented as relative velocity, as precise calibration varies with position of the tag on the body (Baird 1998b), as well as likely variation with body size. Since pilot whale dive depths likely depend in part on the depth of their prey, and many potential prey species may migrate vertically in response to changing light levels, we set the TDR to record light level every $5 \mathrm{~s}$. Light was measured with a photodiode (BPX 63, Siemens Components), which had 
a spectral sensitivity at 350 to $1100 \mathrm{~nm}$, with peak sensitivity at $800 \mathrm{~nm}$. Light values were recorded in uncalibrated units; calibration of the values followed McCafferty et al. (1999), with units converted to illuminance (lux) using the formula: $\ln (\operatorname{lux})=0.13 \times$ TDR output -12 .

Tag bodies were constructed from syntactic foam (to allow tags to float after they fell off) and were attached with an $8 \mathrm{~cm}$ diameter suction cup (Canadian Tire). Tags were attached to the end of a 4 to $5 \mathrm{~m}$ pole and were deployed from both the yacht (5 tags) and the inflatable (1 tag) while the pilot whales were swim-
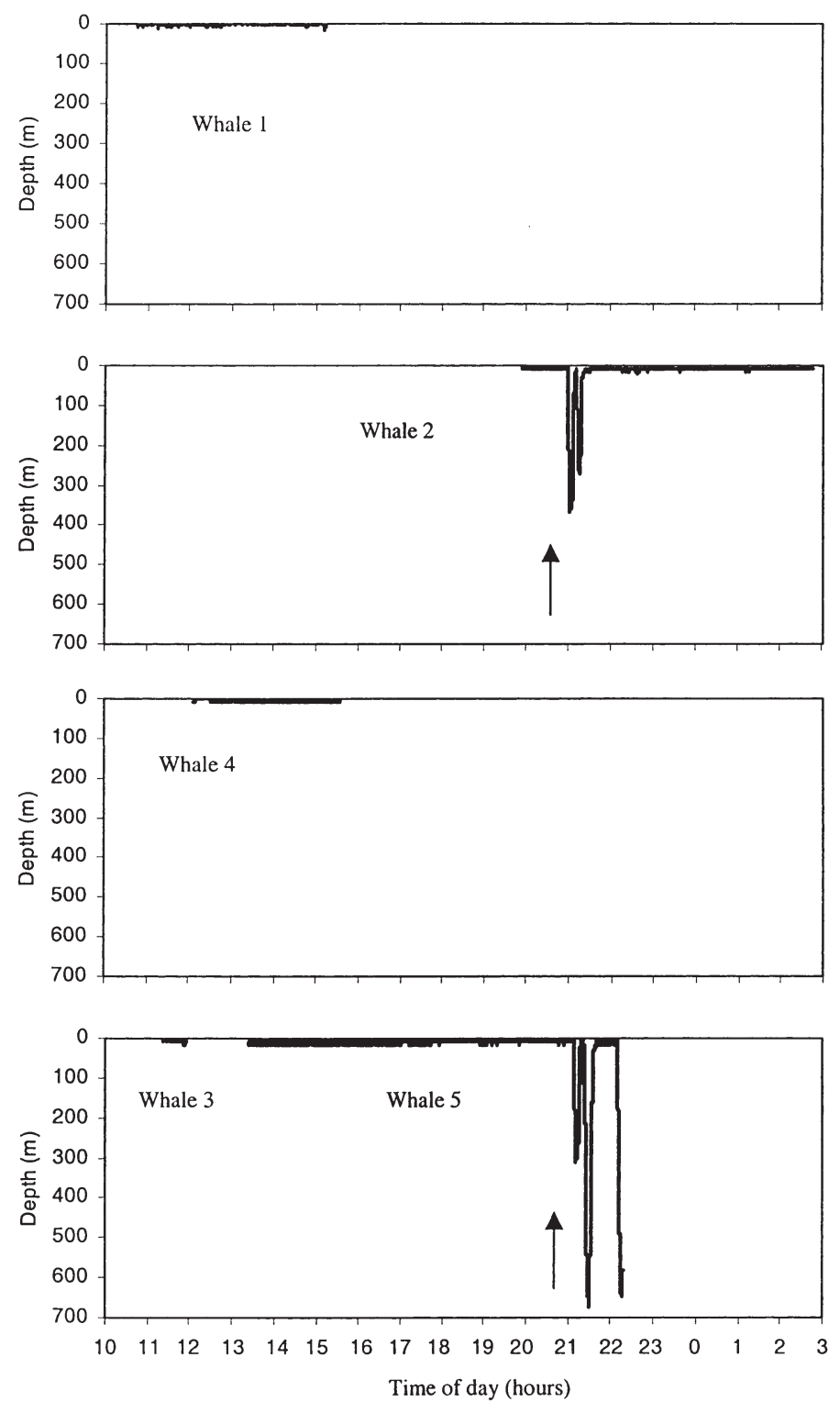

Fig. 1. Dive profiles in relation to time of day. Whale numbers as given in Table 1. Time of sunset indicated by the arrows. The tag for Whale 5 detached at depth, thus the last deep dive shown is incomplete. Water depth throughout was deeper than $2000 \mathrm{~m}$ ming underneath or around the boats. Once tagged, whales were followed with the help of a radio direction finder (ATS) and their location recorded using a GPS in the boat when near the tagged whales. We recorded behavior ad libitum. When tags were recovered, data were downloaded to a computer in a hexadecimal format and were processed using software provided by the TDR manufacturer (Wildlife Computers).

Results and discussion. Long-finned pilot whales were encountered on 1 and 3 August 1999 off the coast of Italy, south of San Remo, in water depths of over $2000 \mathrm{~m}$. On 1 August the whales were first seen approximately $90 \mathrm{~km}$ offshore and traveled a net distance of approximately $25 \mathrm{~km}$ over a $12 \mathrm{~h}$ period. On 3 August the whales were first seen approximately $40 \mathrm{~km}$ offshore and traveled a net distance of approximately $10 \mathrm{~km}$ over a $12 \mathrm{~h}$ period. On both days between 30 and 50 individuals were seen, and up to 15 individuals at one time would bowride on the yacht. Identification photos taken showed no matches between the 2 days; however, only a small number of individuals were identifiable from the photos. Three tags were deployed on each of the 2 days, in a total of 9 tagging attempts (successful attempts shown in Table 1), and 5 of the 6 tags were recovered. The immediate reaction in each case was a fast dive by the tagged animal. In all but 1 case, tagged individuals were easy to approach afterwards and often returned to bowride on the yacht. Shortly after tagging, 1 whale began breaching and rolling on its side until the tag began sliding along the body, coming off after 32 min. Shortly after the tag fell off, this whale returned to the boat and resumed bowriding. Behavior of the whales during daylight hours included directional travel, social/play behavior (e.g. breaching, rolling at the surface, frequent contact between individuals and rubbing against the vessel's hull) and some periods where the tagged whales (and other whales nearby) rested motionless at the surface. Of the 5 tags that were recovered, attachment duration ranged from $32 \mathrm{~min}$ to $9 \mathrm{~h} 48 \mathrm{~min}$ (total = $25 \mathrm{~h}, 3 \mathrm{~min}$; mean $=5 \mathrm{~h}$; Table 1 ) and 2 of the tags remained on after sunset, with 7 h 25 min of night-time data (Fig. 1). Gender of 3 of the tagged whales was confirmed either by observation of the genital region when the whales were rolling at the surface, or based on the larger size and more bulbous head of males (Bernard \& Reilly 1999).

During daylight hours all the tagged whales spent their time in the upper $16 \mathrm{~m}$ of the water column (Fig. 1). Temperature of these surface waters ranged from 19 to $25^{\circ} \mathrm{C}$ (mean $=23.9^{\circ} \mathrm{C}$ for August 3). In both cases when the tags remained on after sunset, deeper dives were documented (Table 2). These included 2 dives for 1 individual (on 1 August, referred to hereafter as Whale 2, see Table 1) and 4 for the other (on 
Table 1. Summary of tags deployed on long-finned pilot whales. Dates given as dd/mm/yy

\begin{tabular}{|c|c|c|c|c|c|c|}
\hline Whale & Date & Time & Age/sex & Duration & Maximum depth & Tag resolution \\
\hline & 01/08/99 & - & - & Tag lost & - & \\
\hline 1 & 01/08/99 & $10: 44$ to $15: 10 \mathrm{~h}$ & Adult male & $4 \mathrm{~h} 26 \mathrm{~min}$ & $16 \mathrm{~m}$ & $2 \mathrm{~m}$ \\
\hline 2 & 01/08/99 & $19: 56$ to $02: 48 \mathrm{~h}$ & Sub-adult-size & 6 h 52 min & $360 \mathrm{~m}$ & $8 \mathrm{~m}$ \\
\hline 3 & 03/08/99 & $11: 23$ to $11: 56 \mathrm{~h}$ & Adult male & $32 \min$ & $16 \mathrm{~m}$ & $8 \mathrm{~m}$ \\
\hline 4 & 03/08/99 & $12: 07$ to $15: 33 \mathrm{~h}$ & Sub-adult-size & $3 \mathrm{~h} 25 \mathrm{~min}$ & $8 \mathrm{~m}$ & $8 \mathrm{~m}$ \\
\hline \multirow[t]{2}{*}{5} & 03/08/99 & $12: 25$ to $22: 17 \mathrm{~h}$ & Sub-adult male & $9 \mathrm{~h} 48 \mathrm{~min}$ & $648 \mathrm{~m}$ & $8 \mathrm{~m}$ \\
\hline & Total & & & 25 h 3 min & & \\
\hline
\end{tabular}

3 August, referred to hereafter as Whale 5); however, the tag for Whale 5 came off at $576 \mathrm{~m}$ depth as the whale was ascending, so the duration of the fourth dive is not known. Dive durations at night ranged from 2.14 to $12.7 \mathrm{~min}$ (Table 2). The deepest dive documented was to $648 \mathrm{~m}$, by Whale 5, a sub-adult male. Water
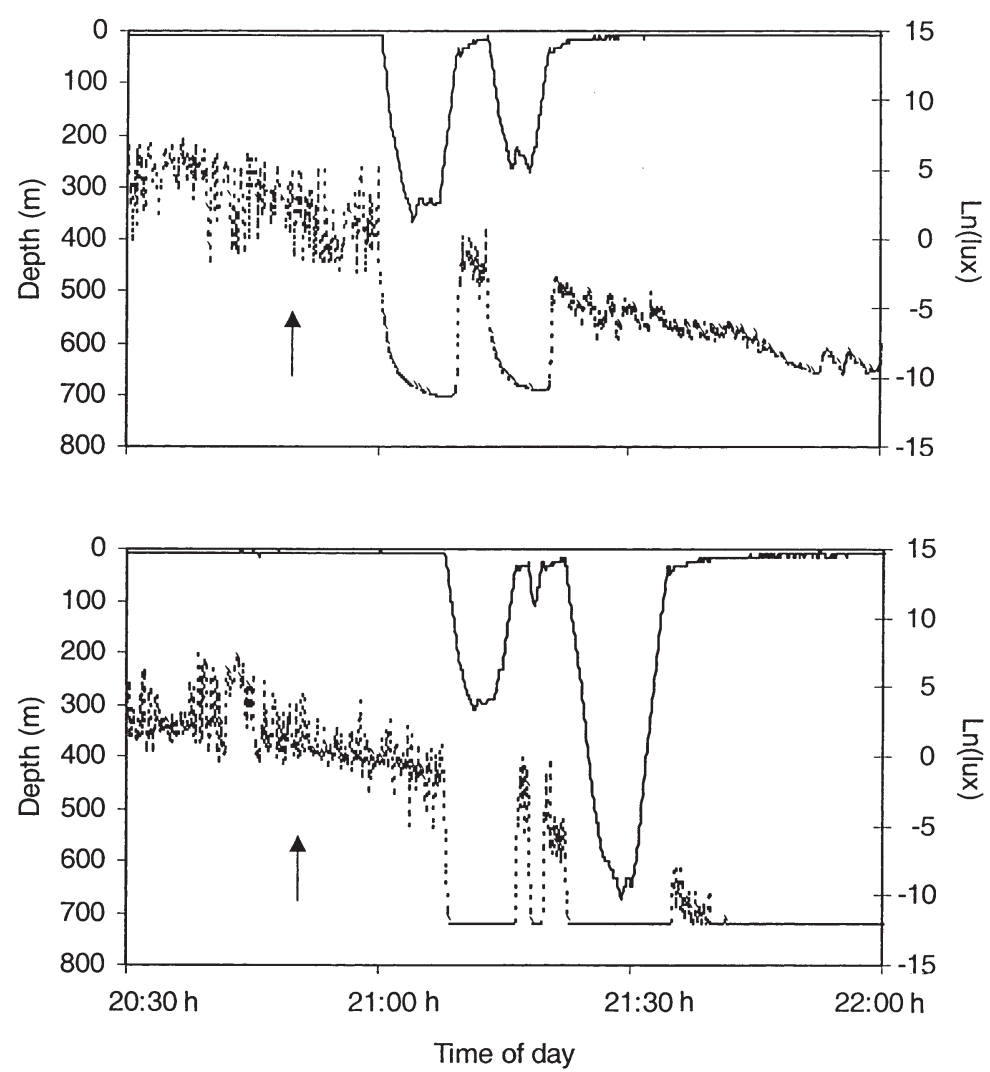

Fig. 2. Dive depth (solid lines) and light (dashed lines) data for Whale 2 (top) and Whale 5 (bottom), with time of sunset indicated by the arrows. Differences in light levels between the 2 whales are likely due to differences in tag position on the whale's body. When light readings for Whale 5 were flat at the deepest points of dives, the light levels were below the minimum detectable by the sensor. Note that temperature-related drift in the surface values (see Hooker \& Baird 2001) results in the end point of dives appearing at depths of approximately $30 \mathrm{~m}$. Thus, while the second dive for Whale 5 appears to be to just over $100 \mathrm{~m}$, corrected maximum depth is $72 \mathrm{~m}$ temperature at depths below $24 \mathrm{~m}$ dropped to 13 to $16^{\circ} \mathrm{C}$ (Whale 5 mean $=14.6^{\circ} \mathrm{C}$ ). Rates of descent for the deep dives ranged between 1.46 and $2.11 \mathrm{~m} \mathrm{~s}^{-1}$ (mean $=1.75, \mathrm{SD}=0.34, \mathrm{n}=6$ ), while rates of ascent were slightly faster (range 1.2 to $2.98 \mathrm{~m} \mathrm{~s}^{-1}$, mean $=2.02, \mathrm{SD}$ $=0.68, \mathrm{n}=5$ ). Such rates are similar to those documented for other mid-sized odontocetes (e.g. Baird 1994, Martin et al. 1994, Martin \& Smith 1999).

It is interesting to note that for the 1 tag which stayed on for a substantial period after sunset (almost $6 \mathrm{~h}$ ), the only deep dives that were recorded were those immediately following sunset. Leatherwood et al. (1973) and Amano \& Baird (1998) found longer and deeper dives at night for 2 tagged short-finned pilot whales in the Pacific Ocean. Light levels at depth during deep dives were similar to light levels found near the surface later at night (Fig. 2). For Whales 2 and 5, velocity during the day (all in the top $16 \mathrm{~m}$ ) was relatively low and variable (Whale 2 mean = $0.762 \mathrm{~m} \mathrm{~s}^{-1}, \mathrm{SD}=0.48$; Whale 5 mean $=0.885 \mathrm{~m}$ $\mathrm{s}^{-1}, \mathrm{SD}=0.63$ ), while velocity at these depths at night was slightly higher (Whale 2 mean $=0.876$ $\mathrm{m} \mathrm{s}^{-1}, \mathrm{SD}=0.49 ;$ Whale 5 mean $=1.258 \mathrm{~m} \mathrm{~s}^{-1}$, $\mathrm{SD}=0.54$; Fig. 3). Within-individual comparisons of velocity during the day versus at night (shallow) were significant for both individuals (MannWhitney $U$-test, $\mathrm{p}<0.0001)$. Velocity at night at greater depths for both individuals was high and less variable (Whale 2 mean $=1.898 \mathrm{~m} \mathrm{~s}^{-1}, \mathrm{SD}=$ 0.67 ; Whale 5 mean $=1.523 \mathrm{~m} \mathrm{~s}^{-1}, \mathrm{SD}=0.64$; Fig. 3). Such variable levels near the surface during the day reflect the diversity of behavior we observed, including rest, social interactions, play behavior and travel, compared to the probable singular function of deeper dives.

Since dive capability generally increases with body size (Schreer \& Kovacs 1997), adult male long-finned pilot whales probably are capable of deeper dives than reported here. Little is known about the diet of long-finned pilot whales in the Mediterranean, although there is some evidence 

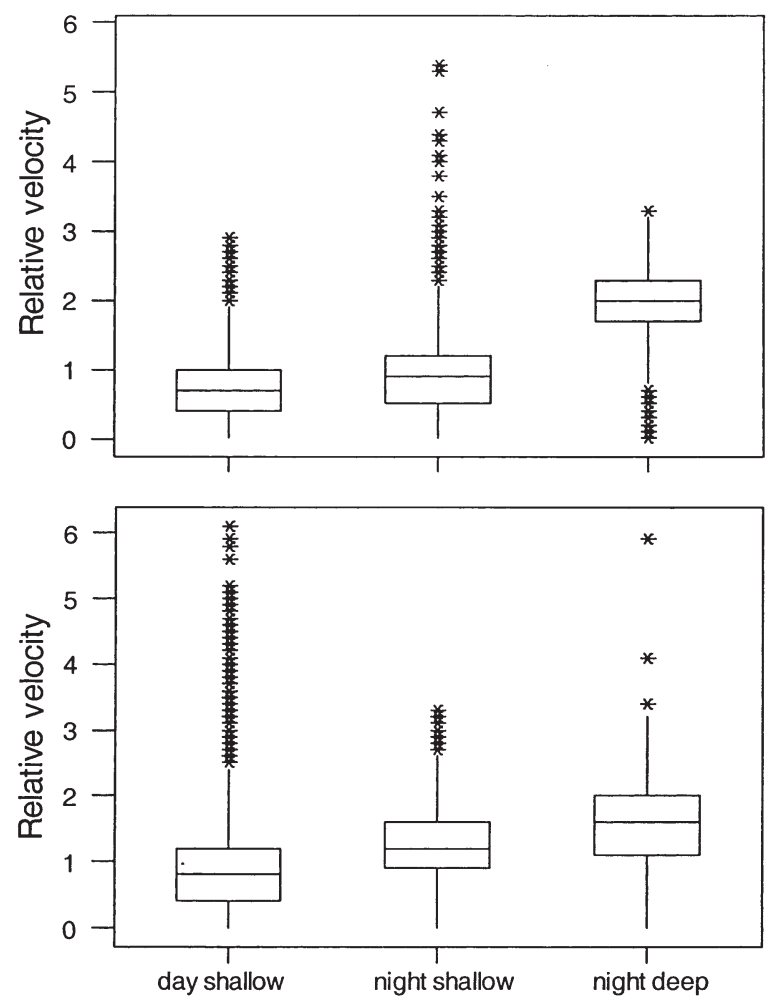

Fig. 3. Box plots (central line $=$ median; box bottom/top $=$ first and third quartile, whiskers and $*=$ data range) of velocity readings for Whale 2 (top) and Whale 5 (bottom). Note that units are relative velocity, not absolute velocity. Deep dives are defined here as $>24 \mathrm{~m}$

that they feed on the European flying squid Todarodes sagittatus (Orsi Relini \& Garibaldi 1992, Canadas \& Sagarminaga 2000), as has been recorded elsewhere in the eastern North Atlantic (Desportes \& Mourtisen 1993). This species of squid is known to show strong diel vertical migrations, being found at depths greater than $1000 \mathrm{~m}$ during the day and near the surface at night (Roper \& Young 1975), presumably in association with deep scattering layer (DSL) organisms. We suggest that the pilot whale deep dives shortly after sunset are feeding dives to (or towards) the DSL, as it moves towards the surface in response to decreasing light levels. Once this layer of organisms has moved closer to the surface, such deep dives would be unnecessary, a possible explanation for the lack of deep dives long after dark. The fact that velocity near the surface after sunset is slightly faster than during the day (Fig. 3) may suggest that feeding occurs near the surface at night, although our time-depth data cannot confirm this suggestion and our sample size is too small. Desportes \& Mouritsen (1993) note some surface feeding of pilot whales on squid at night. It is surprising, however, that the dive depths for Whale 5 did not decrease over time after sunset (Figs. 1 \& 2), as would be expected if the whale was tracking the ascending DSL. Such potential 'tracking' of the rising DSL has been documented with pantropical spotted dolphins Stenella attenuata (Scott et al. 1993, Baird et al. 2001). Because our sample size is limited, further deployments of time-depth recorders on this species and direct sampling at the depths of the dives would be necessary to confirm our suppositions. Because of the ease of approach to long-finned pilot whales in the Ligurian Sea and their tendency to bowride, a behavior not regularly observed for this species elsewhere, time-depth recording studies could easily be undertaken.

Acknowledgements. This research was supported by the US Office of Naval Research under grant no. N00014-99-1-0819. We thank Bob Gisiner and ONR, as well as Woods Hole Oceanographic Institution for administering the contracts. We also thank Alessandro Bocconcelli, Simone Canese and Rossella Di Mento for assisting with tracking of tagged whales, and the crew of the RV 'Bestiaccia'. Sascha Hooker, Tony Martin and 2 anonymous reviewers made helpful comments on the manuscript. This research was undertaken under NMFS Scientific Research Permit 731-1509 issued to R.W.B. This is contribution number 10322 from the Woods Hole Oceanographic Institution.

\section{LITERATURE CITED}

Amano M, Baird RW (1998) Research on the behavior and social structure of the 'Tappanaga', the northern form of the shortfinned pilot whale. In: Uozumi T (ed) Proc 1998 Int Forum on Dolphins and Whales, Muroran, Japan. Volcano Bay Marine Animals Watching Association, Muroran, p 61-62

Baird RW (1994) Foraging behaviour and ecology of transient killer whales (Orcinus orca). PhD thesis, Simon Fraser University, Burnaby, BC

Baird RW (1998a) Studying diving behavior of whales and dolphins using suction-cup attached tags. Whalewatcher $32(1): 3-7$

Table 2. Characteristics of night-time dives of long-finned pilot whales

\begin{tabular}{|c|c|c|c|c|}
\hline Whale & $\begin{array}{l}\text { Dive depth (m) } \\
\text { Mean (SD) and range }\end{array}$ & $\begin{array}{l}\text { Dive duration (min) } \\
\text { Mean (SD) and range }\end{array}$ & $\begin{array}{l}\% \text { Time at bottoma } \\
\text { Mean (SD) and range }\end{array}$ & $\begin{array}{l}\text { No. of } \\
\text { dives }\end{array}$ \\
\hline 2 & 308 (74) 256-360 & $8.3(1.2) \quad 7.42-9.17$ & $23.2(20.1) 9.0-37.4$ & 2 \\
\hline 5 & 416 (280) 72-648 & $7.95(5.36) 2.14-12.7$ & 45.4 (3.3) $41.6-47.6$ & 4 \\
\hline
\end{tabular}


Baird RW (1998b) Preliminary calibration of velocity meters on a captive killer whale. Unpublished report prepared for the Free Willy Keiko Foundation, available from Ocean Futures Society, Santa Barbara

Baird RW, Ligon AD, Hooker SK (2000) Sub-surface and night-time behavior of humpback whales off Maui, Hawaii: a preliminary report. Report prepared under Contract \#40ABNC050729 from the Hawaiian Islands Humpback Whale National Marine Sanctuary, Kihei, HI, to the Hawaii Wildlife Fund, Paia, HI

Baird RW, Ligon AD, Hooker SK, Gorgone AM (2001) Subsurface and nighttime behaviour of pantropical spotted dolphins in Hawaii. Can J Zool 79:988-996

Bernard HJ, Reilly SB (1999) Pilot whales Globicephala Lesson, 1828. In: Ridgway SH, Harrison RJ (eds) Handbook of marine mammals, Vol 6. Academic Press, San Diego, p 245-279

Bowers CA, Henderson RS (1972) Project Deep Ops: deep object recovery with pilot and killer whales. Naval Undersea Center Technical Paper 306, San Diego

Canadas A, Sagarminaga R (2000) The northeastern Alboran Sea, an important breeding and feeding ground for the long-finned pilot whale (Globicephala melas) in the Mediterranean Sea. Mar Mamm Sci 16:513-529

Desportes G, Mouritsen R (1993) Preliminary results on the diet of long-finned pilot whales off the Faroe Islands. Rep Int Whaling Comm Spec Issue 14:305-324

Gannon DP (1995) Foraging ecology of Northwest Atlantic long-finned pilot whales, Globicephala melas (Traill 1809). MA thesis, Bridgewater State College, Bridgewater, MA

Hooker SK, Baird RW (1999) Deep-diving behaviour of the

Editorial responsibility: Kenneth Sherman (Contributing

Editor), Narragansett, Rhode Island, USA northern bottlenose whale, Hyperoodon ampullatus (Cetacea: Ziiphidae). Proc R Soc Lond Ser B 266:671-676

Hooker SK, Baird RW (2001) Diving and ranging behaviour of odontocetes: a methodological review and critique. Mammal Rev 31:81-105

Leatherwood JS, Evans WE, Lingle GE (1973) The Pacific pilot whale Globicephala c.f. G. scammonii: evaluation of its effects on high frequency sonar. Naval Undersea Center Technical Note 1164, San Diego

Martin AR, Smith TG (1999) Strategy and capability of wild belugas, Delphinapterus leucas, during deep, benthic diving. Can J Zool 77:1783-1793

Martin AR, Kingsley MCS, Ramsay MA (1994) Diving behaviour of narwhals (Monodon monoceros) on their summer grounds. Can J Zool 72:118-125

McCafferty DJ, Boyd IL, Walker TR, Taylor RI (1999) Can marine mammals be used to monitor oceanographic conditions? Mar Biol 134:387-395

Orsi Relini L, Garibaldi F (1992) Feeding of the pilot whale, Globicephala melas, in the Ligurian Sea: a preliminary note. In: Evans PGH (ed) Proc 6th Annu Conf Eur Cetacean Soc, San Remo, Italy, 20-22 February 1992. European Cetacean Society, Cambridge, p 142-145

Roper CFE, Young RE (1975) Vertical distribution of pelagic cephalopods. Smithson Contrib Zool 209:1-51

Schreer JF, Kovacs KM (1997) Allometry of diving capacity in air-breathing vertebrates. Can J Zool 75:339-358

Scott MD, Chivers SJ, Olson RJ, Lindsay RJ (1993) Radiotracking of spotted dolphins associated with tuna in the eastern tropical Pacific. In: Abstr 10th Biennial Conf Biology of Marine Mammals, Galveston, TX. Society for Marine Mammalogy, Lawrence, p 97

Submitted: October 14, 2001; Accepted: April 4, 2002

Proofs received from author(s): June 27, 2002 